OPEN ACCESS

Edited by:

Isabel Caçador,

Marine and Environmental Sciences

Centre, Portugal

Reviewed by:

Dongyan Liu,

East China Normal University (ECNU),

China

Edward Clive Pope,

Swansea University, UK

*Correspondence:

Christopher J. Gobler

christopher.gobler@stonybrook.edu

Specialty section:

This article was submitted to

Marine Pollution,

a section of the journal

Frontiers in Marine Science

Received: 30 September 2016

Accepted: 14 December 2016

Published: 04 January 2017

Citation:

Gobler CJ, Clark HR, Griffith AW and Lusty MW (2017) Diurnal Fluctuations

in Acidification and Hypoxia Reduce

Growth and Survival of Larval and

Juvenile Bay Scallops (Argopecten irradians) and Hard Clams (Mercenaria

mercenaria). Front. Mar. Sci. 3:282.

doi: 10.3389/fmars.2016.00282

\section{Diurnal Fluctuations in Acidification and Hypoxia Reduce Growth and Survival of Larval and Juvenile Bay Scallops (Argopecten irradians) and Hard Clams (Mercenaria mercenaria)}

\author{
Christopher J. Gobler ${ }^{1 *}$, Hannah R. Clark ${ }^{1,2}$, Andrew W. Griffith ${ }^{1}$ and Mark W. Lusty ${ }^{1}$ \\ ${ }^{1}$ School of Marine and Atmospheric Sciences, Stony Brook University, Stony Brook, NY, USA, ${ }^{2}$ Mook Sea Farm, Walpole, \\ ME, USA
}

Diurnal variations in $\mathrm{pH}$ and dissolved oxygen (DO) concentrations are common seasonal phenomena in many eutrophic estuaries, yet few studies have investigated the concurrent effects of low pH and low DO on marine organisms inhabiting these coastal systems. Here, we assess the effects of diurnal variations in $\mathrm{pH}$ and $\mathrm{DO}$ on the early-life history of two bivalve species native to Northeast US estuaries, the bay scallop (Argopecten irradians) and hard clam (Mercenaria mercenaria). In one set of experiments, larval- and juvenile-life stage bivalves were exposed to ambient conditions $\left(\mathrm{pH}_{\top} \sim 7.9\right)$, two continuously-low $\mathrm{pH}$ levels $\left(\mathrm{pH}_{\mathrm{T}} \sim 7.3\right.$ and 7.6), and diurnal fluctuations between the ambient and low conditions yielding mean $\mathrm{pH}$ levels equal to the intermediate $\mathrm{pH}$ levels. In a second set of experiments, larval bivalves were exposed to ambient conditions $\left(\mathrm{pH}_{\mathrm{T}} \sim 7.9, \mathrm{DO} \sim 7 \mathrm{mg} \mathrm{L}^{-1}\right)$, two levels of low $\mathrm{pH}$ and $\mathrm{DO}\left(\mathrm{pH}_{\mathrm{T}} \sim 7.2\right.$, DO $\sim 1 \mathrm{mg} \mathrm{L}^{-1}$; $\mathrm{pH}_{\mathrm{T}} \sim 7.4$, DO $\sim 4 \mathrm{mg} \mathrm{L}^{-1}$ ) and diurnal fluctuations of both $\mathrm{pH}$ and $\mathrm{DO}$ between the ambient and low $\mathrm{pH} / \mathrm{DO}$ levels that resulted in mean $\mathrm{pH}$ and $\mathrm{DO}$ levels equal to the intermediate $\mathrm{pH}$ and DO levels. Diurnal acidification treatments with ambient DO levels yielded survival rates for both species at both life stages that were consistent with the survival of individuals exposed to the same mean level of chronic $\mathrm{pH}$ with juveniles being more resistant to acidification than larvae. In contrast, when both $\mathrm{pH}$ and $\mathrm{DO}$ varied diurnally, the survival rates of larval bivalves were significantly lower than the survival of individuals chronically exposed to the same mean levels of $\mathrm{pH}$ and $\mathrm{DO}$, an indication that bivalves were physiologically more vulnerable to concurrent fluctuations of both parameters compared to acidification alone. While both species displayed sensitivities to diurnal fluctuations in $\mathrm{pH}$ and $\mathrm{DO}$, scallops were relatively more susceptible than hard clams. Since many shallow eutrophic estuaries presently experience diurnal cycles of both $\mathrm{pH}$ and $\mathrm{DO}$ when early-life stages of bivalves are present in estuaries, the populations of the bivalves studied are likely impacted by these conditions which are likely to intensify with climate change.

Keywords: ocean acidification, hypoxia, climate change, Argopecten irradians, Mercenaria mercenaria 


\section{INTRODUCTION}

Two consequences of climate change are acidification and deoxygenation of world oceans (Doney et al., 2012). Beyond anthropogenically-induced changes in climate, acidification, and low oxygen conditions are inextricably linked in the ocean via the processes of respiration and photosynthesis and often display highly similar patterns in marine ecosystems (Feely et al., 2010; Cai et al., 2011; Wallace et al., 2014). In temperate coastal zones, hypoxia, or low oxygen conditions as well as acidification develop seasonally as seawater warms, bottom waters become isolated from surface waters via stratification, and rates of respiration accelerate. Many estuaries in particular, are net-heterotrophic due strong internal and external sources of organic carbon, and thus on a net-annual basis produce excess $\mathrm{CO}_{2}$ and consume $\mathrm{O}_{2}$ (Caffrey, 2004; Del Giorgio and Williams, 2005). In urbanized regions receiving excessive nutrient loads (Melzner et al., 2012; Wallace et al., 2014) or within eutrophied river plumes (Cai et al., 2011) hypoxia and acidification can occur at extreme levels. Beyond the role of excessive nutrient loads in driving this trend, specific estuarine habitats such as salt marshes are naturally enriched in organic carbon that when respired can create hypoxic and acidified conditions, particularly within warmer waters (Ringwood and Keppler, 2002; Baumann et al., 2014).

The persistence of hypoxia and acidification in coastal zones can vary from hours (Baumann et al., 2014) to months (Wallace et al., 2014), depending on the intensity of respiration and the hydrodynamics of ecosystems. In shallow, well-mixed estuaries with high rates of respiration, hypoxia and acidification can occur diurnally, as photosynthesis during the day results in high DO and $\mathrm{pH}$ levels, while respiration during night decrease $\mathrm{DO}$ and $\mathrm{pH}$ levels. The intensity of this process can be related to the depth of the water column, given that sediments are known to be strong sources of $\mathrm{CO}_{2}$ and sinks of $\mathrm{O}_{2}$ (Green and Aller, 1998) and their influence is inversely proportional to the depth of the water column (Gobler and Baumann, 2016). Within deeper, stratified ecosystems including oxygen minimum zones (OMZs), hypoxic and acidified water can persist for weeks, months, or longer, as benthic and/or deep water respiration continually consumes oxygen and produces $\mathrm{CO}_{2}$ faster than it is replenished via diffusion and mixing from surface waters (Paulmier et al., 2011; Wallace et al., 2014).

Research regarding of how concurrent acidification and hypoxia impacts marine life is in its infancy. For decades, studies have documented how low oxygen affects ocean organisms, but these studies either ignored $\mathrm{pH}$ levels or, in most cases, treated seawater with nitrogen gas and thus basified, rather than acidified, seawater (Gobler et al., 2014). There have been few studies that have examined how concurrent low oxygen and low $\mathrm{pH}$ affect marine life. Some studies have found that low oxygen effects tend to dominate over $\mathrm{pH}$ effects (Kim et al., 2013) while others have found that the combined effects of acidification and hypoxia are more severe than the effects of each individual stressors and that impacts in bivalves can be age-dependent (Gobler et al., 2014; Steckbauer et al., 2015). Keppel et al. (2016) reported that diel-cycling of DO decreased growth rates of the eastern oyster, Crassostrea virginica, but diel-cycling of $\mathrm{pH}$ did not. Finally, Clark and Gobler (2016) compared the effects of chronic hypoxia and acidification to diurnal fluctuations in $\mathrm{CO}_{2}$ and $\mathrm{O}_{2}$ on larval bivalves and found that diurnal exposure to low $\mathrm{pH}$ and/or low DO rarely altered, and never fully eliminated, the negative effects of hypoxia and/or acidification even when the diurnal cycles yielded higher mean $\mathrm{pH}$ and DO levels. This outcome suggested that the magnitude of $\mathrm{pH}$ and $\mathrm{DO}$ fluctuations may be too intense and/or the duration of normoxic and normocapnic conditions are not of a long enough duration to permit the bivalve larvae to overcome the physiological stress of hypoxia and acidification.

The purpose of this study was to expand on the work conducted by Clark and Gobler (2016) and to further clarify the effects of static vs. diurnally-fluctuating low DO and low $\mathrm{pH}$ on early-life stage bivalves. First, this study compared responses of larval and juvenile life-staged bay scallops (Argopecten irradians) and hard clams (Mercenaria mercenaria) to chronically-low $\mathrm{pH}$ and diurnal fluctuations in $\mathrm{pH}$. Next, this study contrasted diurnal acidification only with that of diurnal changes in $\mathrm{pH}$ and DO in unison, a condition that occurs naturally in ecosystems (Baumann et al., 2014; Wallace et al., 2014). Finally, this study established two separate levels of chronically-low $\mathrm{pH}$ and $\mathrm{DO}$ to compare outcomes to those found for individuals exposed to the diurnal fluctuations to understand whether responses were more similar to the mean or minimum exposure levels of $\mathrm{pH}$ and DO.

\section{METHODS}

\section{Manipulation of Carbonate Chemistry and DO}

Replicate $(n=4) 8 \mathrm{~L}$ polyethylene vessels were used for experiments and filled with UV-sterilized, $0.2 \mu \mathrm{m}$ filtered seawater from Old Fort Pond in Shinnecock Bay, NY, USA (salinity $=30$ ). A constant temperature of $23-24^{\circ} \mathrm{C}$ was maintained by placing experimental vessels in water baths heated by Delta Star ${ }^{\circledR}$ heat pumps. Two types of experiments were conducted. The first involved the manipulation of only $\mathrm{pH}$ while the second involved simultaneous manipulations of both $\mathrm{pH}$ and DO. For first set of experiments, treatments of control $(\sim 7.9)$, intermediate $(\sim 7.5)$, and low $\mathrm{pH}_{T}(\sim 7.2)$ were established and carbonate chemistry was maintained by bubbling mixtures of concentrated $5 \% \mathrm{CO}_{2}$ gas and ambient air into the experimental vessels (details below). An additional treatment of diurnal $\mathrm{pH}$ was included where $\mathrm{pH}$ oscillated between control and low $\mathrm{pH}$ conditions every $12 \mathrm{~h}$ (details below; Figure 1). For the second set of experiments, $\mathrm{pH}$ and $\mathrm{DO}$ levels were altered in unison and four treatments were established: A control treatment $\left(\mathrm{pH}_{\mathrm{T}} \sim\right.$ 7.9, DO $\sim 7.0 \mathrm{mg} \mathrm{L}^{-1}$ ), a chronic-intermediate $\mathrm{pH}$-DO treatment $\left(\sim 7.5, \sim 4.0 \mathrm{mg} \mathrm{L}^{-1}\right)$, a chronic-low $\mathrm{pH}-\mathrm{DO}$ treatment $(\sim 7.2$, $\sim 2.0 \mathrm{mg} \mathrm{L}^{-1}$ ), and a diurnally-fluctuating $\mathrm{pH}-\mathrm{DO}$ treatment that resulted in the control (e.g., ambient conditions) $\mathrm{pH}$ and $\mathrm{DO}$ levels by day and the low $\mathrm{pH}$ and $\mathrm{DO}$ levels at night. Daily-mean levels were similar to the intermediate $\mathrm{pH}$-DO treatments $(\sim 7.5$, $\sim 4.0 \mathrm{mg} \mathrm{L}^{-1}$; details below; Figure 1). The range of $\mathrm{pH}$ and DO variations in all diurnal treatments was consistent with daily fluctuations observed within temperate estuaries in the Northeast 


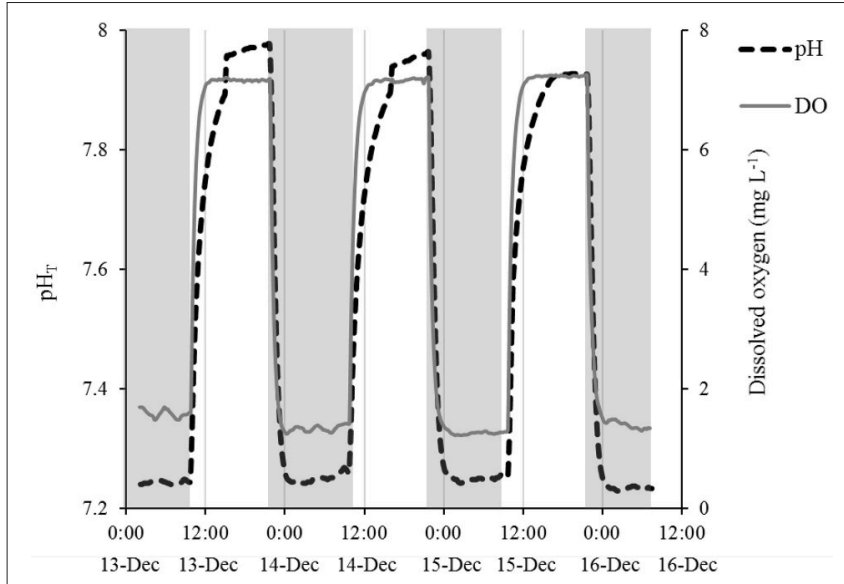

FIGURE 1 | Example of diurnal fluctuations in $\mathrm{pH}$ and DO from an experiment with $\boldsymbol{A}$. irradians larvae. Each day from 0900 to $2100 \mathrm{~h}$, ambient air was bubbled into the experimental vessels to maintain a $\mathrm{pH}_{\mathrm{T}}$ of $\sim 7.9$ and DO concentrations of $\sim 7 \mathrm{mg} \mathrm{L}^{-1}$. From 2100 to $0900, \mathrm{CO}_{2}$ and $\mathrm{N}_{2}$ gases were used to create acidic and hypoxic conditions with a $\mathrm{pH}_{\mathrm{T}}$ of $\sim 7.2$ and DO concentrations of $\sim 2 \mathrm{mg} \mathrm{L}^{-1}$. Shaded regions depict "night" conditions when gases were introduced to lower $\mathrm{pH}$ and DO.

US (Ringwood and Keppler, 2002; Baumann et al., 2014; Wallace et al., 2014).

The delivery rate of gases was controlled by a series of Cole-Parmer ${ }^{\circledR}$ gas regulators, single-channel flowmeters, and/or multi-channel gas proportioners. Carbon dioxide gas was used to manipulate $\mathrm{pH}$ levels while and nitrogen gas to manipulate DO concentrations as described by Gobler et al. (2014). To mimic diurnal patterns of $\mathrm{pH}$ and DO concentrations, Alcon solenoid valves were attached to compressed gas tanks and ambient air lines and were controlled with a Rain Bird- ${ }^{\circledR}$ timer (Clark and Gobler, 2016). During daytime cycles (0900-2100 h), valves on the ambient airlines were opened and the valves controlling the flow for mixed gases $\left(\mathrm{CO}_{2}, \mathrm{~N}_{2}\right.$, and $\left.\mathrm{CO}_{2} \mathrm{~N}_{2}\right)$ were closed to establish ideal $\mathrm{pH}$ and $\mathrm{DO}\left(\mathrm{pH}_{\mathrm{T}}=7.9 ; \mathrm{DO}=7.0 \mathrm{mg} \mathrm{L}^{-1}\right)$ conditions. At night $(2100-0900 \mathrm{~h})$, the valves on the appropriate $\mathrm{CO}_{2}, \mathrm{~N}_{2}$, or $\mathrm{CO}_{2} \mathrm{~N}_{2}$ gas tanks were opened to establish low $\mathrm{pH}$ and/or DO conditions.

\section{Measuring Salinity, Temperature, $\mathrm{pH}$, and DO}

Salinity was measured using a YSI 600QS multi-parameter water quality sonde and temperature was logged every 15 min using a HOBO ${ }^{\circledR}$ U-002-64 Data Logger (Onset). Measurements of $\mathrm{pH}_{\mathrm{T}}$ were made daily using a Honeywell Durafet Ion Sensitive Field Effect Transistor (ISFET)-based $\mathrm{pH}$ sensor calibrated with a seawater $\mathrm{pH}$ standard (Dickson, 1993). Every $15 \mathrm{~min}$, in the diurnal treatments, $\mathrm{pH}$ values were measured and logged with a Thermo-Scientific Orion STAR A321 pH meter to quantify diurnal patterns of $\mathrm{pH}$. A Clark-type electrode YSI 5100 oxygen meter was used to make daily DO measurements and DO was logged every $15 \mathrm{~min}$ on a $\mathrm{HOBO}^{\circledR} \mathrm{U} 26$ dissolved oxygen logger (Onset) in the diurnal treatments. Prior studies have found these instruments measure levels of dissolved oxygen that are indistinguishable from discrete measurements made with Winkler titrations (Gobler et al., 2014).

Samples were obtained for dissolved inorganic carbon (DIC) analysis at the beginning and end of each experiment and were quantified using an EGM-4, Environmental Gas Analyzer- ${ }^{\circledR}$ (PP Systems) system after separation of gas and liquid phases with a Liqui-Cel- ${ }^{\circledR}$ Membrane (Membrana). For all diurnal treatments, samples were collected and analyzed from the end of both the day and night cycles. To determine the precision and accuracy of DIC measurements, Dr. Andrew Dickson's (University of California San Diego, Scripps Institution of Oceanography) certified reference material for DIC was analyzed during each analytical run (mean percent recovery of DIC across all analytical runs: $103 \pm 6 \%$ ). DIC levels, along with $\mathrm{pH}$, temperature, salinity, pressure, phosphate, silicate, and carbonic acid dissociation constants recommended for estuarine waters (Millero et al., 2006) were analyzed with the CO2SYS program (http://cdiac. ornl.gov/ftp/co2sys/) in order to quantify levels of $p \mathrm{CO}_{2}, \Omega_{\text {calcite }}$,

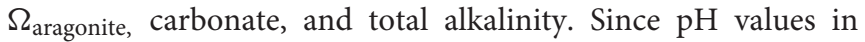
some experimental treatments fluctuated widely each day and since $\mathrm{pH}$ is on a log scale, mean $\mathrm{pH}$ values were determined by first converting $\mathrm{pH}$ to $\left[\mathrm{H}^{+}\right]$concentrations. Mean $\left[\mathrm{H}^{+}\right]$ concentrations were then converted back to $\mathrm{pH}$.

\section{Care and Maintenance of Organisms}

All organisms used for this study were marine invertebrates and as such, ethical approval for their use was not required. Larval and juvenile A. irradians and M. mercenaria were obtained from the East Hampton Town Shellfish Hatchery located in Montauk, NY, USA. Experimental vessels ( $8 \mathrm{~L})$ were stocked with either 10,000 D-stage larvae $(<24 \mathrm{~h})$ or 15 juveniles (initial size of juvenile $A$. irradians $=2 \pm 0.1 \mathrm{~mm} ; M$. mercenaria $=7 \pm 0.5 \mathrm{~mm})$. All shellfish were fed a diet of live-cultured algae $\left(4 \times 10^{4}\right.$ cells $\mathrm{mL}^{-1}$; Isochrysis galbana $)$ daily (Kraeuter and Castagna, 2001; Helm et al., 2004). Full water changes were performed twice-weekly for experiments involving larval shellfish, during which the entire contents of each experimental vessel was carefully poured over a $64 \mu \mathrm{m}$ sieve to capture larvae. Larvae collected on the sieve were condensed into a $50 \mathrm{~mL}$ container and $2 \mathrm{~mL}$ aliquots were removed and preserved with a $3 \%$ solution of buffered formalin phosphate to assess mortality, size (distance from the umbo to furthest-leading ventral edge), and developmental stage (veliger, pediveliger, or fully-metamorphosed) at each time-point using a compound microscope with Nikon DigiSight Color Digital Camera System (DSVi1) and Image ${ }^{(\subset)}$ software. Live larvae were distinguishable from dead larvae by the pigmentation, presence or absence of internal organs, and whether or not valves were fully intact. Percent metamorphosis was determined based upon the total number of surviving larvae at each time-point. Larval experiments concluded when the majority of individuals had fully metamorphosed within control treatments, 11 and 15 days for $M$. mercenaria and A. irradians respectively. Final growth rates $\left(\mu \mathrm{m} \mathrm{day}^{-1}\right.$ ) were calculated using initial (length at $24 \mathrm{~h}$ post-fertilization) and final shell lengths.

For experiments involving juvenile shellfish, water was exchanged in each experimental vessel twice weekly. 
Survival was assessed daily, whereby dead individuals, deemed so by their gaping shells and/or lack of response to external stimulate, were removed. Initial and final size, determined using digital calipers, was used to determine growth rates. Juvenile experiments were concluded after $\sim 1$ month.

\section{Data Analysis}

All statistical analyses were performed using RStudio ${ }^{(}$(http:// www.cran.r-project.org) statistical software. Survival and development data were arcsine-square-root transformed before analysis. A one-way analysis of variance (ANOVA) was used to detect differences in survival, development, and growth among treatments for all experiments (Table 1). A ShapiroWilk's test was used to verify experimental data was normally distributed and Bartlett's test was used confirm homogeneity of variance amongst each dataset. When significant differences were detected, a Tukey's honest significant difference test (Tukey HSD) was used to identify the source of variance. All results were deemed significant at $\alpha \leq 0.05$.

\section{RESULTS}

\section{Diurnal Acidification Experiments with Larval Bivalves}

Survival of larval $A$. irradians was significantly reduced by low $\mathrm{pH}$ (one-way ANOVA; $p<0.001$; Figure 2A; Table 1). Larvae exposed to control and intermediate $\mathrm{pH}$ levels $\left(\mathrm{pH}_{\mathrm{T}}=7.94 \pm\right.$ 0.06 and $7.60 \pm 0.03$, respectively) experienced $36 \pm 2$ and 21 $\pm 11 \%$ survival ( \pm standard deviation), respectively, whereas the percentage of larvae that survived in low $\mathrm{pH}$ treatments $\left(\mathrm{pH}_{\mathrm{T}}\right.$ $=7.33 \pm 0.07$; survival $=7 \pm 5 \%$ ) was significantly lower than the intermediate (Tukey HSD; $p<0.05$ ) and control (Tukey HSD; $p<0.01)$ treatments, but not different than the diurnal treatments (mean $\mathrm{pH}_{\mathrm{T}}=7.47 \pm 0.43$; survival $=15 \pm 3 \%$; Figure 2A; Table 1). Low $\mathrm{pH}$ conditions slowed larval growth (one-way ANOVA; $p<0.001$ ) and delayed metamorphosis (oneway ANOVA; $p<0.001)$ relative to control treatments, whereas intermediate and diurnal $\mathrm{pH}$ treatments had no discernible effect on growth or development (Figures 2B,C). Larvae grew at a rate of $11 \pm 5 \mu \mathrm{m} \mathrm{day}^{-1}$ in low $\mathrm{pH}$ treatments, $26 \pm 4 \mu \mathrm{m}$ day $^{-1}$ in control treatments, $20 \pm 2 \mu \mathrm{m} \mathrm{day}^{-1}$ in intermediate $\mathrm{pH}$ treatments, and $22 \pm 3 \mu \mathrm{m}$ day $^{-1}$ in diurnal $\mathrm{pH}$ treatments (Figure 2B). Twelve days post-fertilization, $88 \pm 5,58 \pm 22$, and $61 \pm 19 \%$ of $A$. irradians larvae had metamorphosed in the control, intermediate, and diurnal treatments respectively, while only $13 \pm 19 \%$ had metamorphosed in low $\mathrm{pH}$ treatments (Figure 2C).

Low $\mathrm{pH}\left(\mathrm{pH}_{\mathrm{T}}=7.29 \pm 0.06\right)$ significantly reduced survival (one-way ANOVA; $p<0.05$ ) of larval $M$. mercenaria, although there was no effect of intermediate $\left(\mathrm{pH}_{\mathrm{T}}=7.58 \pm 0.04\right)$ or diurnally-fluctuating $\mathrm{pH}$ treatments (mean $\mathrm{pH}_{\mathrm{T}}=7.54 \pm 0.36$; Figure 3A; Table 2). Larvae reared under control $\left(\mathrm{pH}_{\mathrm{T}}=7.91 \pm\right.$ 0.02 ), intermediate, and diurnal $\mathrm{pH}$ conditions displayed survival rates of $27 \pm 3,23 \pm 2$, and $25 \pm 5 \%$, respectively, whereas the survival of larvae in the low $\mathrm{pH}$ treatment was $15 \pm 5 \%$, significantly lower than all other treatments (Tukey HSD; $p$ $<0.05$; Figure 3A; Table 2). Growth and development of $M$. mercenaria larvae did not differ significantly among experimental treatments (one-way ANOVA; $p>0.05$; Figures 3B,C).

\section{Diurnal Acidification Experiments with Juvenile Bivalves}

Relative to control (e.g., ideal) $\mathrm{pH}$ treatments, survival of juvenile A. irradians was significantly reduced by low $\mathrm{pH}\left(\mathrm{pH}_{\mathrm{T}}=7.13\right.$ \pm 0.03; Tukey HSD; $p<0.05)$, intermediate $\mathrm{pH}\left(\mathrm{pH}_{\mathrm{T}}=\right.$ $7.49 \pm 0.04$; Tukey HSD; $p<0.01$ ), and diurnally-fluctuating $\mathrm{pH}$ conditions (mean $\mathrm{pH}_{\mathrm{T}}=7.57 \pm 0.43$; Tukey HSD; $p<$ 0.001; Figure 4A; Table 3). In the control treatment $\left(\mathrm{pH}_{\mathrm{T}}=\right.$ $7.92 \pm 0.05), 92 \pm 6 \%$ of individuals survived whereas low, intermediate, and diurnally-fluctuating $\mathrm{pH}$ treatments displayed $57 \pm 25,47 \pm 9$, and $40 \pm 12 \%$ survival, respectively, levels significantly lower than the control (Tukey HSD; $p<0.05$ ) but not significantly different from each other (Tukey HSD; $p>0.05$; Figure 4A). There was no effect of $\mathrm{pH}$ on the growth of juvenile A. irradians (Figure 4B). The differing levels of $\mathrm{pH}$ (Table 4) used in experiments did not significantly alter the survival and growth of juvenile $M$. mercenaria (Figures 5A,B).

TABLE 1 | Mean ( \pm standard deviation) $\mathrm{pH}, \mathrm{pCO}_{2}$, saturation states of calcite and aragonite, total dissolved inorganic carbon (TDIC), carbonate, total alkalinity (TA), salinity, and temperature for the larval Argopecten irradians diurnal acidification experiment.

\begin{tabular}{|c|c|c|c|c|c|c|}
\hline \multirow[t]{2}{*}{ Parameter } & \multicolumn{3}{|c|}{ Continuous } & \multicolumn{3}{|c|}{ Diurnal } \\
\hline & Control & Intermediate & Low & Day & Night & Mean \\
\hline $\mathrm{pH}_{\mathrm{T}}$ & $7.94 \pm 0.06$ & $7.60 \pm 0.03$ & $7.33 \pm 0.07$ & $7.87 \pm 0.02$ & $7.32 \pm 0.08$ & $7.47 \pm 0.43$ \\
\hline $\mathrm{pCO}_{2}$ ( $\left.\mu \mathrm{atm}\right)$ & $516 \pm 18$ & $1200 \pm 134$ & $2340 \pm 384$ & $662 \pm 148$ & $2700 \pm 907$ & $1680 \pm 527$ \\
\hline$\Omega_{\text {calcite }}$ & $3.44 \pm 0.82$ & $1.61 \pm 0.10$ & $0.90 \pm 0.16$ & $3.15 \pm 0.69$ & $0.99 \pm 0.20$ & $2.07 \pm 0.45$ \\
\hline$\Omega_{\text {aragonite }}$ & $2.21 \pm 0.53$ & $1.04 \pm 0.06$ & $0.58 \pm 0.10$ & $2.03 \pm 0.44$ & $0.64 \pm 0.13$ & $1.33 \pm .03$ \\
\hline TDIC $\left(\mu \mathrm{mol} \mathrm{L}{ }^{-1}\right)$ & $1930 \pm 269$ & $1970 \pm 94$ & $2030 \pm 82$ & $2090 \pm 473$ & $2290 \pm 467$ & $2190 \pm 470$ \\
\hline $\mathrm{CO}_{3}^{2-}\left(\mu \mathrm{mol} \mathrm{L}{ }^{-1}\right)$ & $136 \pm 33$ & $63.7 \pm 3.9$ & $35.4 \pm 6.1$ & $125 \pm 28$ & $39.2 \pm 7.9$ & $81.9 \pm 18$ \\
\hline $\mathrm{TA}\left(\mu \mathrm{mol} \mathrm{L}^{-1}\right)$ & $2110 \pm 307$ & $2030 \pm 89$ & $2010 \pm 80$ & $2250 \pm 495$ & $2260 \pm 444$ & $2250 \pm 469$ \\
\hline Salinity & $28.3 \pm 0.58$ & $28.3 \pm 0.58$ & $28.3 \pm 0.58$ & $28.3 \pm 0.58$ & $28.3 \pm 0.58$ & $28.3 \pm 0.58$ \\
\hline Temperature $\left({ }^{\circ} \mathrm{C}\right)$ & $23.5 \pm 0.52$ & $23.5 \pm 0.52$ & $23.5 \pm 0.52$ & $23.5 \pm 0.52$ & $23.5 \pm 0.52$ & $23.5 \pm 0.52$ \\
\hline
\end{tabular}




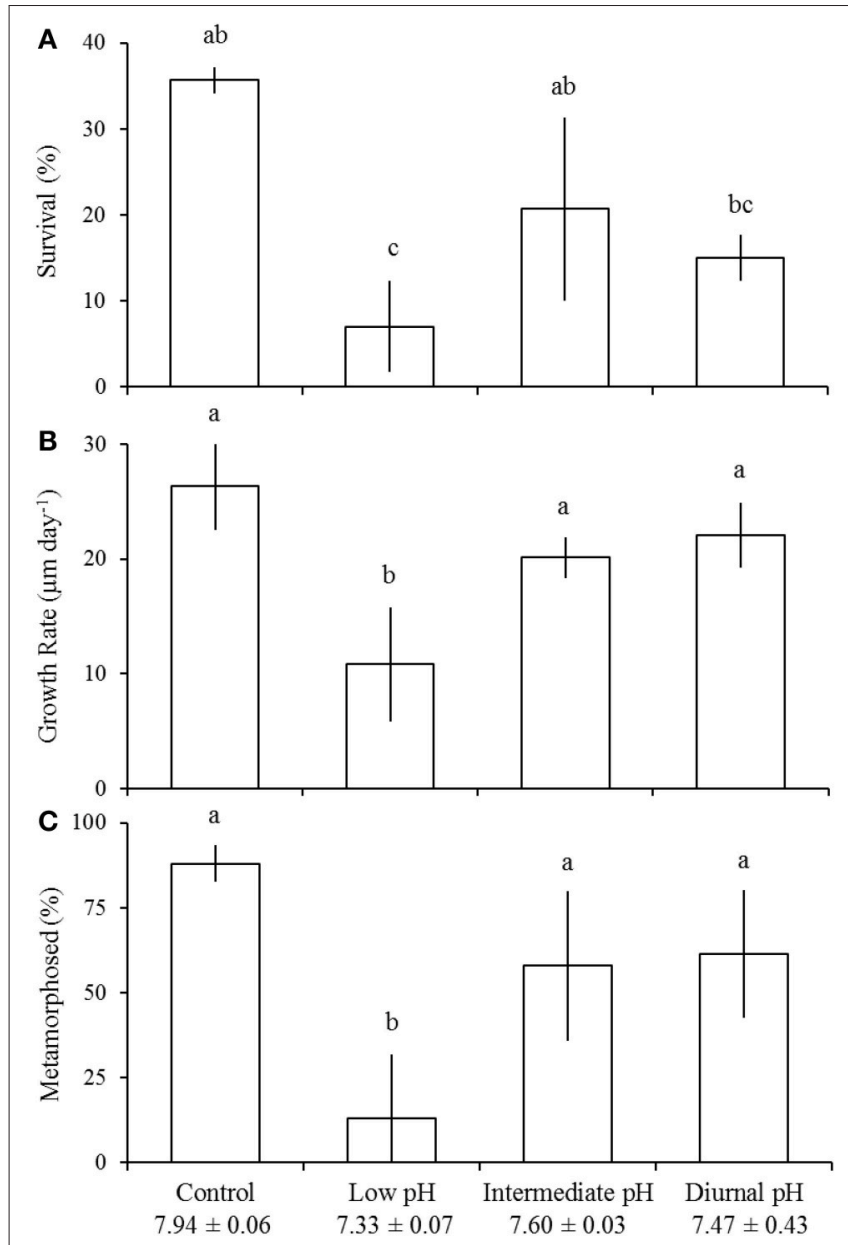

FIGURE 2 | Survival (A), growth (B), and development (C) of Argopecten irradians larvae in the diurnal acidification experiment (Table 1). Percent metamorphosis was determined 12 days post-fertilization. Error bars represent standard deviation $(n=4)$. Lowercase letters indicate significant differences among treatments.

\section{Diurnal Acidification and Hypoxia \\ Experiments with Larval Bivalves}

Chronic and diurnal exposure to low $\mathrm{pH}$ and low DO significantly (one-way ANOVA; $p<0.05$ ) reduced survival of larval A. irradians (Figure 6A). The survival of larval $A$. irradians in the control $\left(38 \pm 11 \%\right.$; $\mathrm{pH}_{\mathrm{T}}=7.89 \pm 0.00 ; \mathrm{DO}=6.87 \pm$ $0.25 \mathrm{mg} \mathrm{L}^{-1}$ ) was significantly (Tukey HSD; $p<0.05$ ) greater than larvae at intermediate levels $\left(26 \pm 6 \%\right.$; $\mathrm{pH}_{\mathrm{T}}=7.48 \pm 0.05$; $\mathrm{DO}=4.08 \pm 0.41 \mathrm{mg} \mathrm{L}^{-1}$ ) which was significantly (Tukey HSD; $p<0.05)$ greater than larvae exposed to low $\left(16 \pm 4 \% ; \mathrm{pH}_{\mathrm{T}}\right.$ $\left.=7.22 \pm 0.05 ; \mathrm{DO}=1.38 \pm 0.45 \mathrm{mg} \mathrm{L}^{-1}\right)$ and diurnal $(6 \pm$ $1 \%$; mean $\mathrm{pH}_{\mathrm{T}}=7.61 \pm 0.26$; mean $\mathrm{DO}=4.11 \pm 2.80 \mathrm{mg}$ $\mathrm{L}^{-1}$ ) treatments (Figure 6A; Table 5). Both the low and diurnal treatment slowed growth (one-way ANOVA; $p<0.001$ ) from $13 \pm 1 \mu \mathrm{m} \mathrm{day}^{-1}$ in both the control and intermediate $\mathrm{pH}-\mathrm{DO}$ treatments to $7 \pm 1$ and $10 \pm 0.4 \mu \mathrm{m} \mathrm{day}^{-1}$ in the low and diurnal $\mathrm{pH}-\mathrm{DO}$ treatments (Figure 6B). Continuously-low $\mathrm{pH}$ and DO also significantly delayed development (one-way ANOVA; $p<$

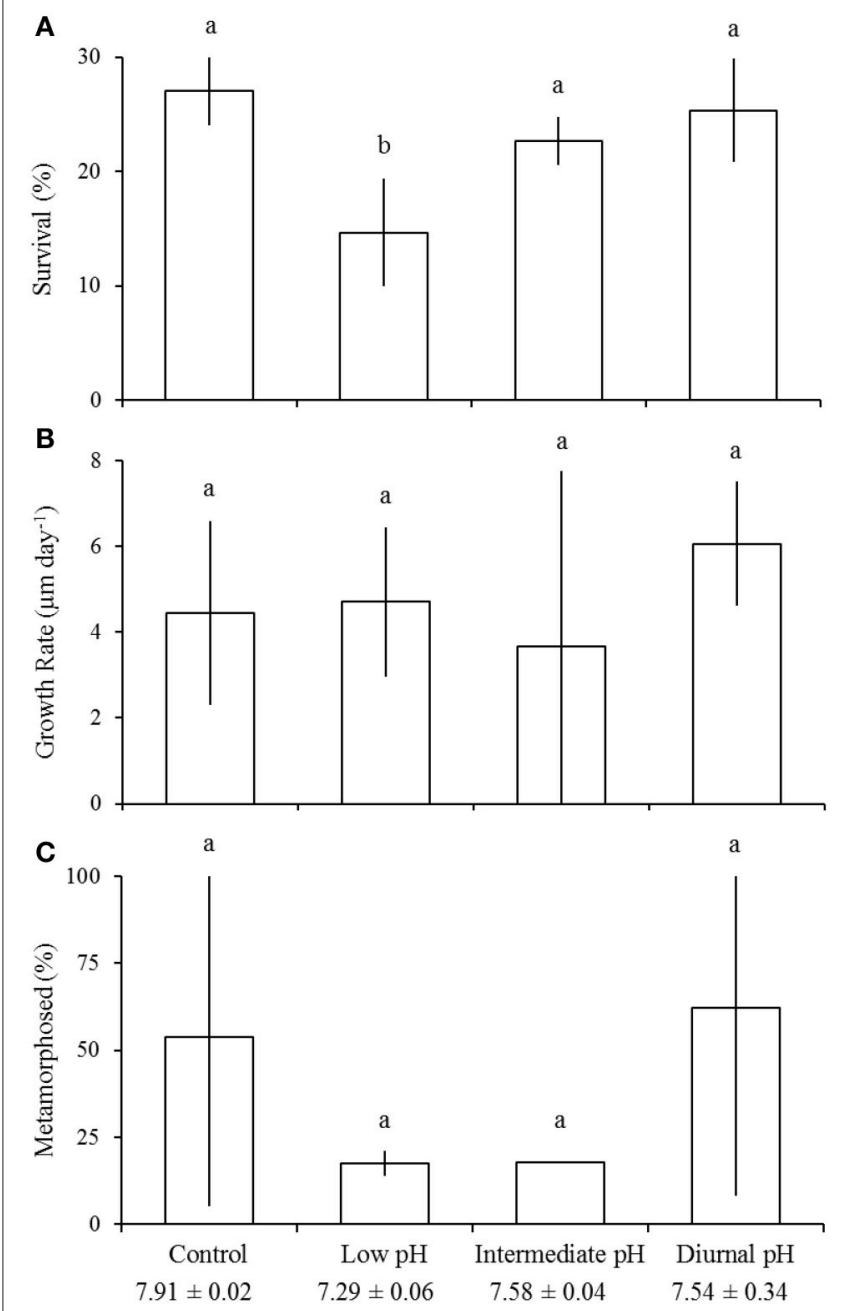

FIGURE 3 | Survival (A), growth (B), and development (C) of Mercenaria mercenaria larvae in the diurnal acidification experiment (Table 2). Percent metamorphosis was determined 18 days post-fertilization. Error bars represent standard deviation $(n=4)$. Lowercase letters indicate significant differences among treatments.

0.05), while exposure to intermediate and diurnally-fluctuating $\mathrm{pH}$ and DO had no effect. After 15 days, $32 \pm 8,36 \pm 4$, and $32 \pm$ $13 \%$ of larvae had metamorphosed in the control, intermediate, and diurnal $\mathrm{pH}-\mathrm{DO}$ treatments respectively, whereas only 13 $\pm 3 \%$ had metamorphosed in the low pH-DO treatment (Figure 6C).

Exposure of larval $M$. mercenaria to low $\left(\mathrm{pH}_{\mathrm{T}}=7.24 \pm\right.$ 0.04 ; $\left.\mathrm{DO}=1.32 \pm 0.30 \mathrm{mg} \mathrm{L}^{-1}\right)$ and diurnally-fluctuating $\mathrm{pH}$ DO $\left(\right.$ mean $\mathrm{pH}_{T}=7.41 \pm 0.34$; mean $\mathrm{DO}=4.02 \pm 3.00 \mathrm{mg}$ $\mathrm{L}^{-1}$ ) significantly (Tukey HSD; $p<0.05$ ) reduced survival to $15 \pm 5$ and $10 \pm 4 \%$ compared to the control $\left(\mathrm{pH}_{\mathrm{T}}=7.87\right.$ $\left.\pm 0.03 ; \mathrm{DO}=6.92 \pm 0.13 \mathrm{mg} \mathrm{L}^{-1}\right)$ and intermediate $\left(\mathrm{pH}_{\mathrm{T}}=\right.$ $\left.7.43 \pm 0.03 ; \mathrm{DO}=3.92 \pm 0.34 \mathrm{mg} \mathrm{L}^{-1}\right) \mathrm{pH}$ treatments that had survival of $29 \pm 4$ and $20 \pm 4 \%$, respectively (Figure 7A; Table 6). Continuously-low $\mathrm{pH}$ and DO conditions significantly $(p<$ 0.05; Tukey HSD) slowed the growth of $M$. mercenaria larvae relative to control treatments. Growth among the remaining 
TABLE 2 | Mean ( \pm standard deviation) pH, $\mathrm{pCO}_{2}$, saturation states of calcite and aragonite, total dissolved inorganic carbon (TDIC), carbonate, total alkalinity (TA), salinity, and temperature for the larval Mercenaria mercenaria diurnal acidification experiment.

\begin{tabular}{|c|c|c|c|c|c|c|}
\hline \multirow[t]{2}{*}{ Parameter } & \multicolumn{3}{|c|}{ Continuous } & \multicolumn{3}{|c|}{ Diurnal } \\
\hline & Control & Intermediate & Low & Day & Night & Mean \\
\hline $\mathrm{pH}_{\mathrm{T}}$ & $7.91 \pm 0.02$ & $7.58 \pm 0.04$ & $7.29 \pm 0.06$ & $7.82 \pm 0.06$ & $7.27 \pm 0.05$ & $7.54 \pm 0.34$ \\
\hline $\mathrm{pCO}_{2}$ ( $\left.\mu \mathrm{atm}\right)$ & $643 \pm 169$ & $1390 \pm 309$ & $2800 \pm 593$ & $792 \pm 320$ & $2900 \pm 710$ & $1850 \pm 515$ \\
\hline$\Omega_{\text {calcite }}$ & $2.53 \pm 0.09$ & $1.24 \pm 0.07$ & $0.67 \pm 0.08$ & $1.99 \pm 0.21$ & $0.61 \pm 0.07$ & $1.30 \pm 0.14$ \\
\hline$\Omega$ aragonite & $1.63 \pm 0.06$ & $0.80 \pm 0.05$ & $0.43 \pm 0.06$ & $1.28 \pm 0.13$ & $0.40 \pm 0.05$ & $0.84 \pm 0.09$ \\
\hline TDIC $\left(\mu \mathrm{mol} \mathrm{L}^{-1}\right)$ & $1820 \pm 238$ & $1850 \pm 205$ & $1940 \pm 253$ & $1750 \pm 294$ & $1900 \pm 269$ & $1820 \pm 282$ \\
\hline $\mathrm{CO}_{3}^{2-}\left(\mu \mathrm{mol} \mathrm{L}{ }^{-1}\right)$ & $100 \pm 3.9$ & $49.2 \pm 3.2$ & $26.5 \pm 3.7$ & $78.9 \pm 7.7$ & $24.4 \pm 3.0$ & $51.6 \pm 5.4$ \\
\hline $\mathrm{TA}\left(\mu \mathrm{mol} \mathrm{L}^{-1}\right)$ & $1950 \pm 234$ & $1880 \pm 197$ & $1890 \pm 240$ & $1850 \pm 278$ & $1850 \pm 251$ & $1850 \pm 264$ \\
\hline Salinity & $28.5 \pm 3.5$ & $28.5 \pm 3.5$ & $28.5 \pm 3.5$ & $28.5 \pm 3.5$ & $28.5 \pm 3.5$ & $28.5 \pm 3.5$ \\
\hline Temperature $\left({ }^{\circ} \mathrm{C}\right)$ & $23.0 \pm 0.25$ & $23.0 \pm 0.25$ & $23.0 \pm 0.25$ & $23.0 \pm 0.25$ & $23.0 \pm 0.25$ & $23.0 \pm 0.25$ \\
\hline
\end{tabular}
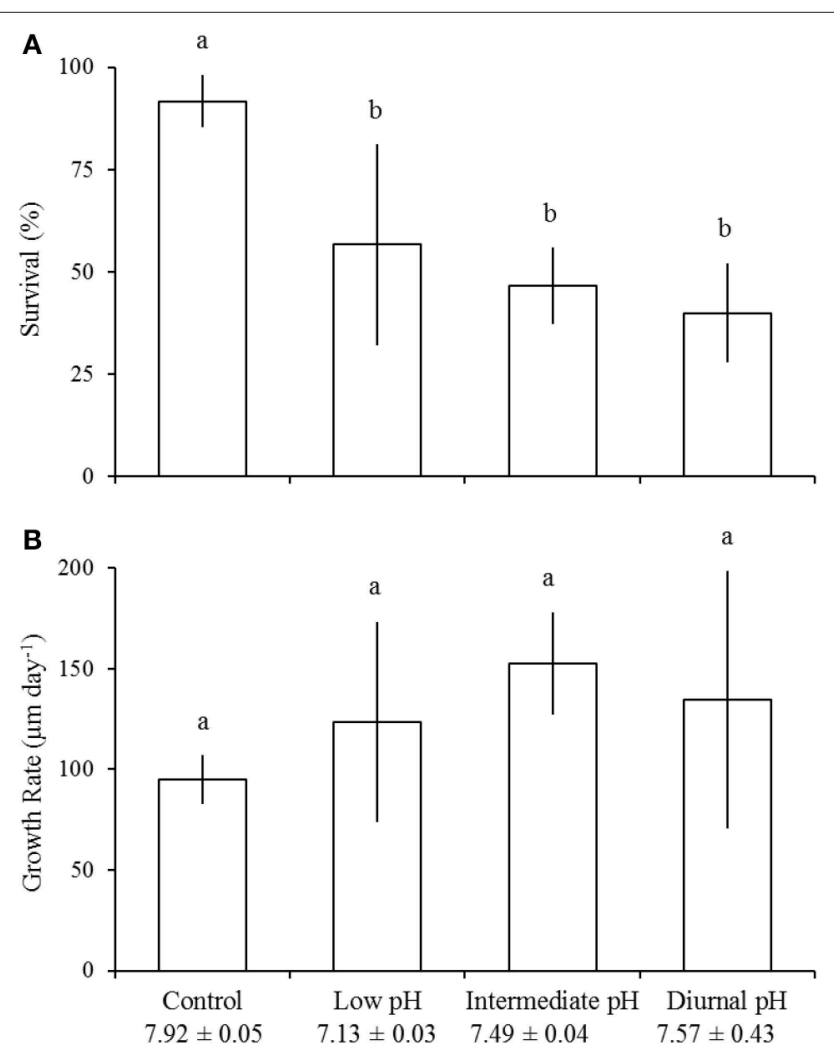

FIGURE 4 | Survival (A) and growth (B) of juvenile Argopecten irradians in the diurnal acidification experiment (Table 3). Error bars represent standard deviation $(n=4)$. Lowercase letters indicate significant differences among treatments.

treatments was not statistically different ( $p>0.05$; Tukey HSD). Delays in development were only observed in M. mercenaria larvae exposed to lower $\mathrm{pH}$ and DO (Tukey HSD); $p<0.05$; Figure 7C). Eleven days post-fertilization, $61 \pm 4 \%$ of larvae had metamorphosed in the control treatment, whereas only $41 \pm 7$, $28 \pm 9$, and $24 \pm 7 \%$ had metamorphosed in the intermediate (Tukey HSD; $p<0.05$ ), diurnal ( $p<0.001)$, and low $\mathrm{pH}-\mathrm{DO}$ (Tukey HSD; $p<0.001$ ) treatments respectively (Figure 7C).

\section{DISCUSSION}

Low oxygen and low $\mathrm{pH}$ conditions are a common feature of many eutrophic estuaries today and these conditions are expected to be intensified by climate change in coming decades (Diaz and Rosenberg, 2008; Doney et al., 2009). While the detrimental effects of hypoxia and acidification on marine life have been well-studied, the combined impacts of these stressors are poorly understood (Gobler et al., 2014). Early-life stage bivalves are spawned during early-summer months, a period when $\mathrm{pH}$ and DO can be concurrently low but also undergo sharp diurnal changes (Ringwood and Keppler, 2002; Wootton et al., 2008; Baumann et al., 2014). Prior studies investigating the effects of continuous acidification and hypoxia on early-life stage bivalves have found these stressors can have additive and synergisticallynegative effects (Gobler et al., 2014) and that diurnal variation in these conditions do not provide a refuge for larval-stage bivalves (Clark and Gobler, 2016). This study builds on these findings by demonstrating that although diurnal exposure of larvae to low $\mathrm{pH}$ alone yielded survival rates consistent with chronic exposure to similar mean $\mathrm{pH}$ conditions, the concurrent cycling of both $\mathrm{pH}$ and DO to low levels on diurnal time-scales yielded lower survival outcomes than individuals exposed to chronic levels of the same mean levels (e.g., intermediate treatments) of $\mathrm{pH}$ and DO. This study further demonstrated that juvenile-stage bivalves are more resistant to acidification, both chronic and diurnal, than larval stages and that $A$. irradians is more vulnerable to acidification than $M$. mercenaria. Collectively, these findings bring novel insight regarding the fate of bivalve populations in current and future coastal ecosystems.

During the past decade, acidification has been identified as a considerable environmental threat to early-life stage bivalves (Talmage and Gobler, 2009; Gazeau et al., 2013; Kroeker et al., 2013). Early-shell formation in bivalve larvae is an energetically expensive process that becomes an even greater challenge when acidification reduces the availability of carbonate ions (Pörtner, 2008; Waldbusser et al., 2013) and recent studies have emphasized the significant physiological stress wrought by enhanced acid-base regulation (Pörtner et al., 2004; Sokolova, 2013; Waldbusser et al., 2015). While chronic exposure to 
TABLE 3 | Mean ( \pm standard deviation) pH, $\mathrm{pCO}_{2}$, saturation states of calcite and aragonite, total dissolved inorganic carbon (TDIC), carbonate, total alkalinity (TA), salinity, and temperature for the juvenile Argopecten irradians diurnal acidification experiment.

\begin{tabular}{|c|c|c|c|c|c|c|}
\hline \multirow[t]{2}{*}{ Parameter } & \multicolumn{3}{|c|}{ Continuous } & \multicolumn{3}{|c|}{ Diurnal } \\
\hline & Control & Intermediate & Low & Day & Night & Mean \\
\hline $\mathrm{pH}_{\mathrm{T}}$ & $7.92 \pm 0.05$ & $7.49 \pm 0.04$ & $7.13 \pm 0.03$ & $7.87 \pm 0.05$ & $7.51 \pm 0.10$ & $7.57 \pm 0.43$ \\
\hline $\mathrm{pCO}_{2}$ ( $\mu$ atm) & $527 \pm 132$ & $1510 \pm 146$ & $3070 \pm 375$ & $990 \pm 232$ & $522 \pm 50$ & $756 \pm 141$ \\
\hline$\Omega_{\text {calcite }}$ & $3.32 \pm 0.18$ & $1.34 \pm 0.15$ & $0.52 \pm 0.10$ & $2.35 \pm 0.41$ & $3.15 \pm 0.23$ & $2.75 \pm 0.32$ \\
\hline$\Omega_{\text {aragonite }}$ & $2.16 \pm 0.12$ & $0.88 \pm 0.09$ & $0.34 \pm 0.06$ & $1.53 \pm 0.27$ & $2.05 \pm 0.15$ & $1.79 \pm 0.21$ \\
\hline TDIC $\left(\mu \mathrm{mol} \mathrm{L}^{-1}\right)$ & $1860 \pm 259$ & $1950 \pm 96$ & $1760 \pm 235$ & $2090 \pm 306$ & $1810 \pm 26$ & $1950 \pm 166$ \\
\hline $\mathrm{CO}_{3}^{2-}\left(\mu \mathrm{mol} \mathrm{L}{ }^{-1}\right)$ & $134 \pm 7.4$ & $54.2 \pm 5.8$ & $21.2 \pm 3.9$ & $94.6 \pm 17$ & $127 \pm 9.3$ & $111 \pm 13$ \\
\hline $\mathrm{TA}\left(\mu \mathrm{mol} \mathrm{L}^{-1}\right)$ & $2050 \pm 254$ & $1990 \pm 98$ & $1700 \pm 230$ & $2200 \pm 305$ & $1990 \pm 21$ & $2090 \pm 163$ \\
\hline Salinity & $30.7 \pm 0.58$ & $30.7 \pm 0.58$ & $30.7 \pm 0.58$ & $30.7 \pm 0.58$ & $30.7 \pm 0.58$ & $30.7 \pm 0.58$ \\
\hline Temperature $\left({ }^{\circ} \mathrm{C}\right)$ & $23.7 \pm 0.48$ & $23.7 \pm 0.48$ & $23.7 \pm 0.48$ & $23.7 \pm 0.48$ & $23.7 \pm 0.48$ & $23.7 \pm 0.48$ \\
\hline
\end{tabular}

TABLE 4 | Mean ( \pm standard deviation) $\mathrm{pH}, \mathrm{pCO}_{2}$, saturation states of calcite and aragonite, total dissolved inorganic carbon (TDIC), carbonate, total alkalinity (TA), salinity, and temperature for the juvenile Mercenaria mercenaria diurnal acidification experiment.

\begin{tabular}{|c|c|c|c|c|c|c|}
\hline \multirow[t]{2}{*}{ Parameter } & \multicolumn{3}{|c|}{ Continuous } & \multicolumn{3}{|c|}{ Diurnal } \\
\hline & Control & Intermediate & Low & Day & Night & Mean \\
\hline $\mathrm{pH}_{\mathrm{T}}$ & $7.86 \pm 0.05$ & $7.57 \pm 0.03$ & $7.25 \pm 0.03$ & $7.83 \pm 0.05$ & $7.35 \pm 0.12$ & $7.57 \pm 0.33$ \\
\hline $\mathrm{pCO}_{2}$ ( $\left.\mu \mathrm{atm}\right)$ & $561 \pm 93$ & $1140 \pm 65$ & $2500 \pm 267$ & $605 \pm 112$ & $1940 \pm 391$ & $1270 \pm 252$ \\
\hline$\Omega_{\text {calcite }}$ & $2.52 \pm 0.16$ & $1.38 \pm 0.16$ & $0.69 \pm 0.09$ & $2.30 \pm 0.30$ & $0.88 \pm 0.32$ & $1.59 \pm 0.31$ \\
\hline$\Omega$ aragonite & $1.62 \pm 0.10$ & $0.89 \pm 0.12$ & $0.44 \pm 0.06$ & $1.48 \pm 0.20$ & $0.57 \pm 0.21$ & $1.02 \pm 0.21$ \\
\hline TDIC $\left(\mu \mathrm{mol} \mathrm{L}^{-1}\right)$ & $1690 \pm 117$ & $1760 \pm 107$ & $1850 \pm 155$ & $1670 \pm 213$ & $1770 \pm 136$ & $1720 \pm 174$ \\
\hline $\mathrm{CO}_{3}^{2-}\left(\mu \mathrm{mol} \mathrm{L}{ }^{-1}\right)$ & $98.9 \pm 6.3$ & $54.3 \pm 7.8$ & $27.1 \pm 3.7$ & $90.6 \pm 13$ & $34.6 \pm 13$ & $62.6 \pm 13$ \\
\hline $\mathrm{TA}\left(\mu \mathrm{mol} \mathrm{L}^{-1}\right)$ & $1820 \pm 116$ & $1800 \pm 117$ & $1810 \pm 154$ & $1790 \pm 222$ & $1760 \pm 166$ & $1780 \pm 194$ \\
\hline Salinity & $27.5 \pm 2.1$ & $27.5 \pm 2.1$ & $27.5 \pm 2.1$ & $27.5 \pm 2.1$ & $27.5 \pm 2.1$ & $27.5 \pm 2.1$ \\
\hline Temperature $\left({ }^{\circ} \mathrm{C}\right)$ & $23.3 \pm 0.61$ & $23.3 \pm 0.61$ & $23.3 \pm 0.61$ & $23.3 \pm 0.61$ & $23.3 \pm 0.61$ & $23.3 \pm 0.61$ \\
\hline
\end{tabular}

acidification has been shown to lead to enhanced mortality in larval and juvenile A. irradians, larval M. mercenaria, and slowed growth in juvenile $M$. mercenaria (Talmage and Gobler, 2010, 2011; Gobler and Talmage, 2013), in this study exposure to only diurnal acidification provided some relief from these effects. For example, for both species, larval-stage growth, survival and development were not statistically different to the rates found within the chronic-intermediate acidification treatments with highly similar mean $\mathrm{pH}$ levels, despite nightly excursions into extremely low $\mathrm{pH}$ conditions. This finding implies that when experiencing only the stress of acidification, these bivalve larvae can resist, daily extreme acidification $\left(\mathrm{pH}_{\mathrm{T}}\right.$ $\sim 7.3$ ) if such excursions are followed by extended normal $\mathrm{pH}$ conditions.

This study documented stage-specific vulnerability of bivalves to acidification. The larval life stages of both species were highly vulnerable to low $\mathrm{pH}$ conditions in terms of growth, survival, and development, while juvenile-life stages were less affected. Neither species exhibited slower growth in response to low $\mathrm{pH}$ conditions, and only bay scallops displayed reduced survivorship. Prior work has demonstrated that bivalve larvae tend to be the most sensitive life stage to acidification (Widdicombe and Spicer, 2008; Talmage and Gobler, 2011; Gazeau et al., 2013), likely due to the very large energy expenditure associated with initial calcium carbonate shell formation (Waldbusser et al., 2013, 2014). For example, within $48 \mathrm{~h}$ of fertilization, larvae precipitate roughly $90 \%$ of their body weight as calcium carbonate (Waldbusser et al., 2013), a process that is severely disrupted under low $\mathrm{pH}$ conditions (Gobler and Talmage, 2013; Waldbusser et al., 2013).

The larval-life stages can be a significant population bottleneck for bivalve molluscs (Kraeuter et al., 1981; Kraeuter and Castagna, 2001). In the field, $<1 \%$ of spawned individuals reach post-set (i.e., juvenile) life-stages (Vance, 1973; Fegley, 2001). Here, we demonstrate that extreme-diurnal variation in $\mathrm{pH}$ and $\mathrm{DO}$ in coastal areas may further limit shellfish recruitment in highly productive or eutrophic regions experiencing such conditions. Future climate changes may depress the baseline and/or enhance the intensity of such diurnal fluctuations (Wootton et al., 2008; Miller et al., 2009) and may add additional selective pressure on shellfish populations, especially during initial life stages. Prior studies have shown that acidification induced mortality can depress the productivity of whole bivalve populations (O'Leary et al. submitted). Further, bivalve shellfish perform several ecological functions within coastal marine ecosystems such as the establishment of critical 

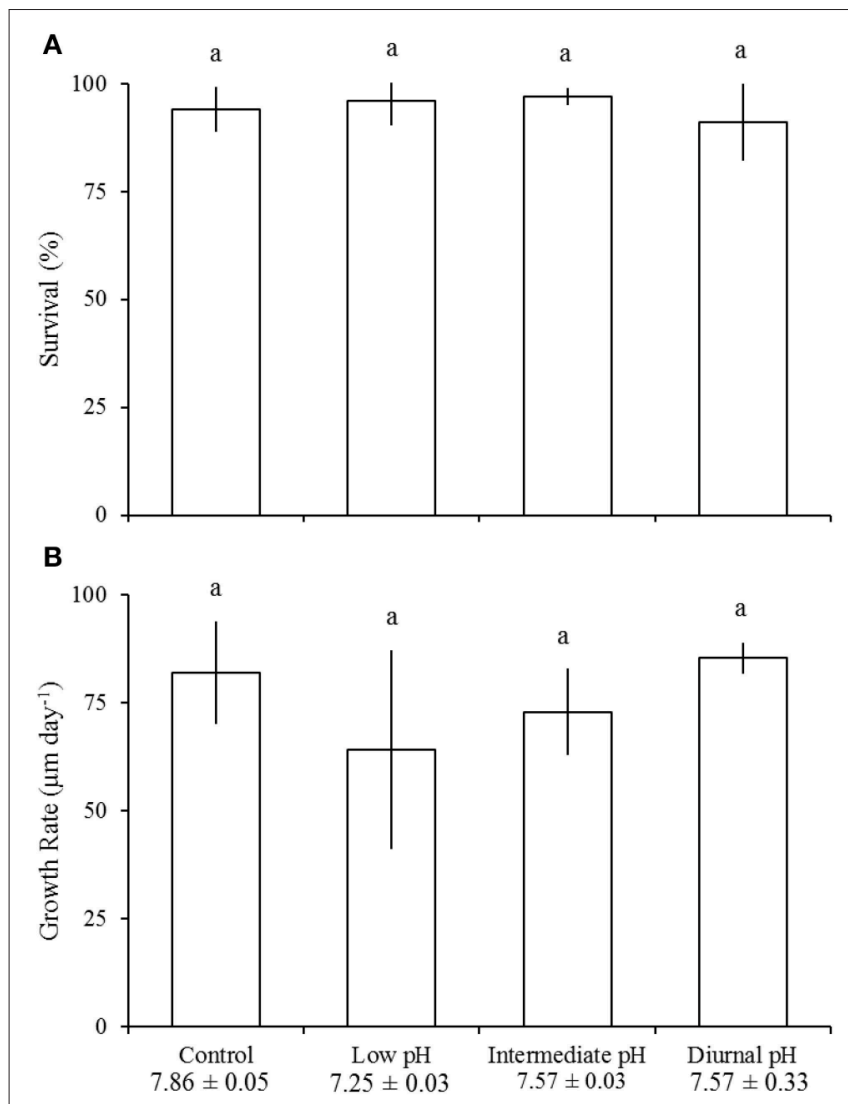

FIGURE 5 | Survival (A) and growth (B) of juvenile Mercenaria mercenaria in the diurnal acidification experiment (Table 4). Error bars represent standard deviation $(n=4)$. Lowercase letters indicate significant differences among treatments.

habitat (Tolley and Volety, 2005; Abeels et al., 2012), decreasing coastal erosion (Meyer et al., 1997; Coen et al., 2007), and improve the surrounding water quality through the removal of suspended particulates (Officer et al., 1982; Wall et al., 2008). Finally, shellfish also provide a significant source of income and economic stimulus within coastal communities (Shumway et al., 2003; Ekstrom et al., 2015). Therefore, extreme variations in $\mathrm{pH}$ and $\mathrm{DO}$ on diurnal time-scales may represent a current and potentially growing threat to these ecologically and economically valuable marine resources.

Juvenile stages of bivalves were less vulnerable to acidification than larvae stages. In contrast to larvae, juvenile-stage bivalves can rely on internal stores of inorganic carbon to synthesize calcium carbonate shell (Gazeau et al., 2013), making them less vulnerable to physiological stressors. For hard clams, $M$. mercenaria, the age-specific vulnerability has been identified previously, with older individuals such as those used in this study being more resistant to low $\mathrm{pH}$ conditions (Green et al., 2009; Gobler et al., 2014). Interestingly, such resistance can be lost in juvenile hard clams when they are concurrently exposed to acidification and hypoxia (Gobler et al., 2014), a finding consistent with the results of this study, at least for larval stages (see below).
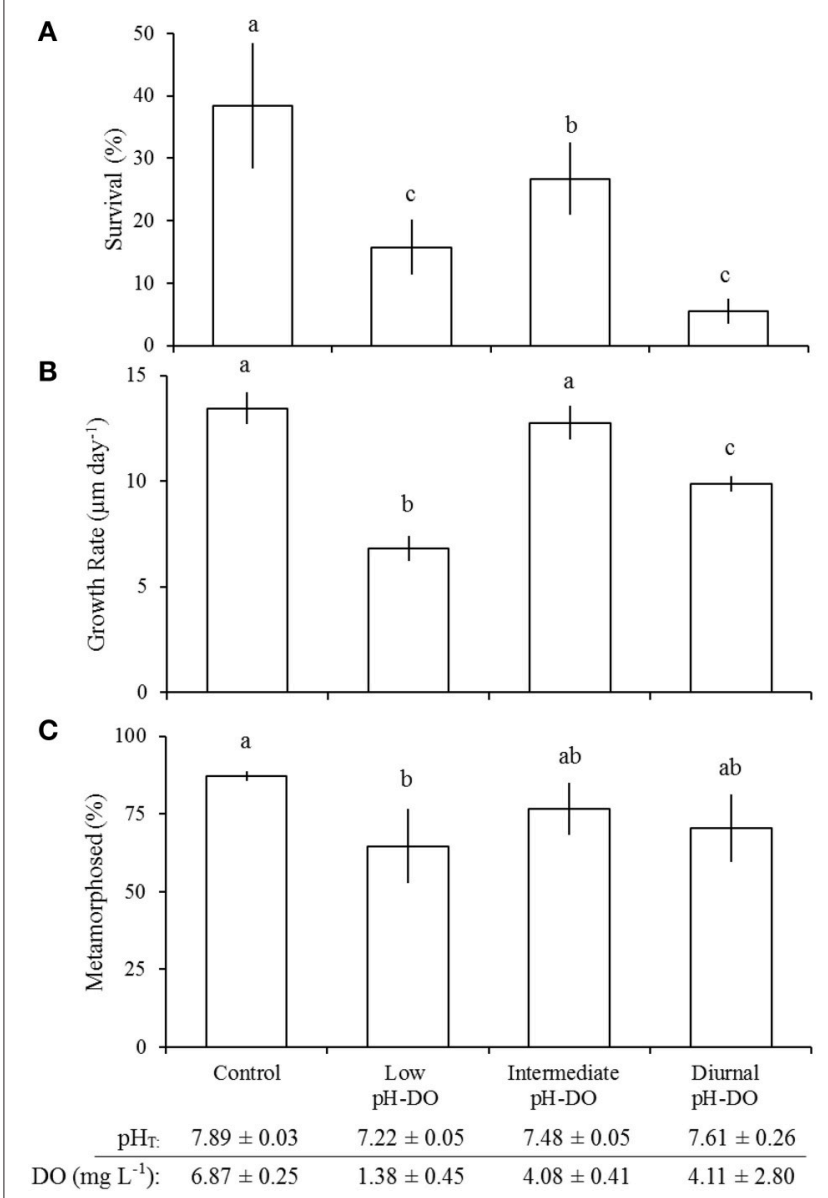

FIGURE 6 | Survival (A), growth (B), and development (C) of Argopecten irradians larvae in the diurnal pH - DO experiment (Table 5). Percent metamorphosis was determined 12 days post-fertilization. Error bars represent standard deviation $(n=4)$. Lowercase letters indicate significant differences among treatments.

During this study, both stages of M. mercenaria were markedly more tolerant to acidification than $A$. irradians, a finding consistent with prior studies of these two species (Talmage and Gobler, 2009, 2010). Juvenile hard clams were entirely tolerant of the low $\mathrm{pH}$ they were exposed to, a trait potentially related to their position in the seabed relative to bay scallops. Scallops are epifaunal, live on the sediment surface, and are thus exposed to overlying water column chemistry, whereas hard clams are infaunal, burrowed in coastal sediments that are naturally acidified and are often exposed to porewaters that are undersaturated in calcium carbonate (Green and Aller, 1998; Green et al., 2009). The differential vulnerability of these populations to acidification has important implications for regional restoration efforts (e.g., Tettelbach et al., 2015). Future efforts in regions where both bivalve species exist and diurnal patterns of $\mathrm{pH}$ and $\mathrm{DO}$ are extreme may seek to focus on the more resilient, $M$. mercenaria, over A. irradians, which is more susceptible to the imminent intensification of acidification predicted to occur this century (Doney et al., 2009; O'Leary et al. submitted). 
TABLE 5 | Mean ( \pm standard deviation) $\mathrm{pH}$, dissolved oxygen (DO), $p \mathrm{CO}_{2}$, saturation states of calcite and aragonite, total dissolved inorganic carbon (TDIC), carbonate, total alkalinity (TA), salinity, and temperature for the four treatment larval Argopecten irradians diurnal acidification and hypoxia experiment.

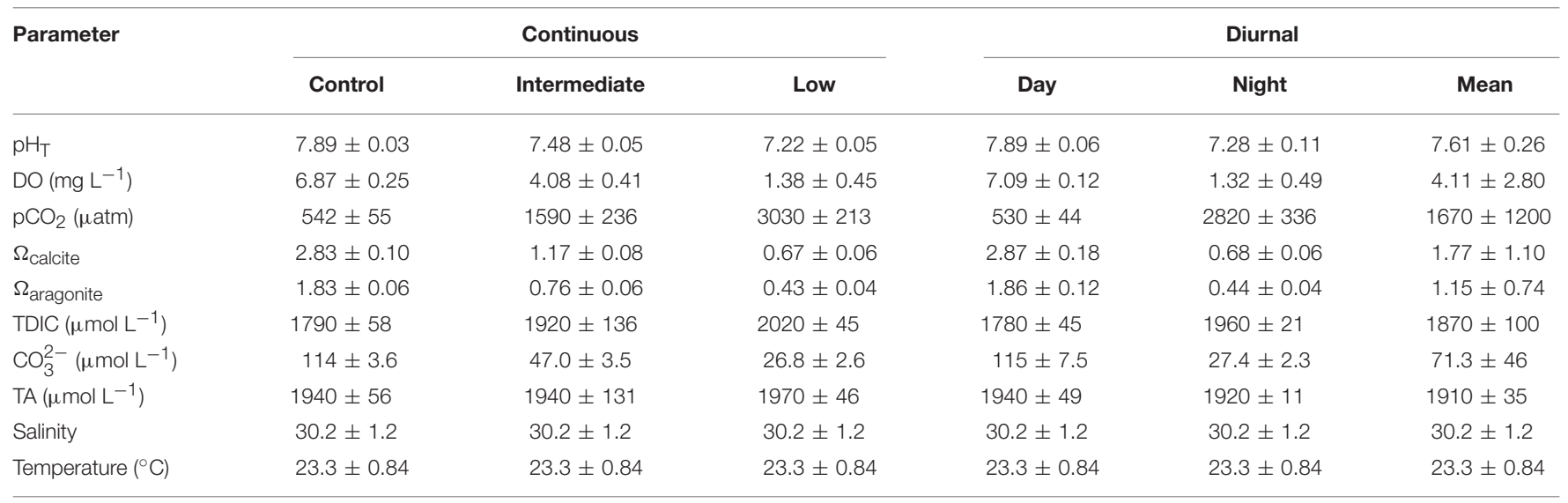

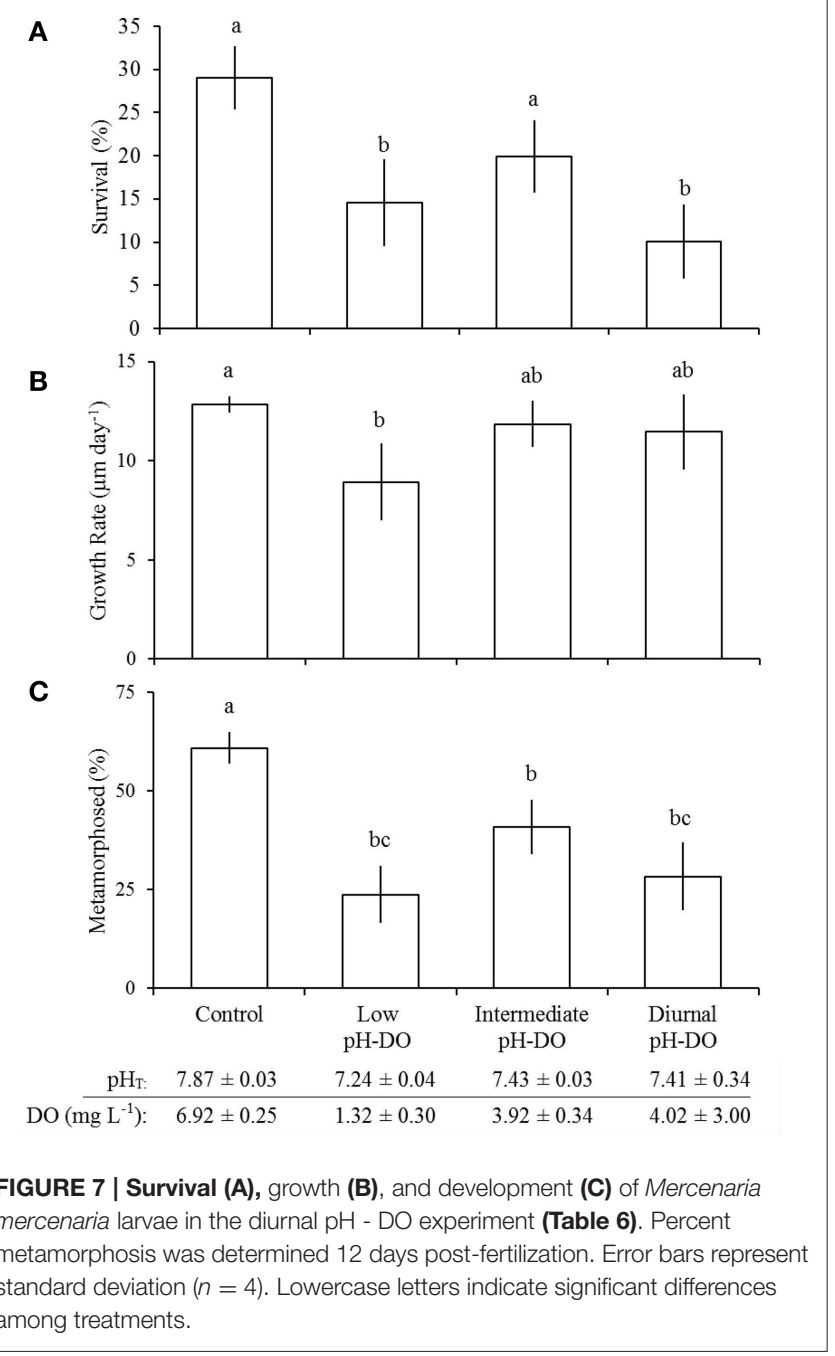

A growing body of literature has documented the common and widespread nature of concurrent hypoxia and acidification in estuaries, particularly those that are eutrophic (Cai et al.,
2011; Melzner et al., 2012; Wallace et al., 2014) and has shown that these conditions can be chronic or can vary diurnally in parallel with ecosystem metabolism (Ringwood and Keppler, 2002; Yates et al., 2007; Baumann et al., 2014). Due to the intimate linkage of $\mathrm{DO}$ and $\mathrm{CO}_{2}$ associated with photosynthesis and respiration, the examination of only acidification or hypoxia without consideration of the other costressor is environmentally unrealistic. Similarly, in shallow, eutrophic estuaries, the consideration of only the continuous exposure of marine animals to acidification and hypoxia may not be reflective of ecosystem conditions. This study, therefore, sought to consider concurrent, diel changes in $\mathrm{pH}$ and $\mathrm{DO}$ reflective of the manner in which these variables cycle in shallow, temperate estuaries during summer (Ringwood and Keppler, 2002; Yates et al., 2007; Baumann et al., 2014). The patterns, intensity, and duration of diel acidification and hypoxia in coastal ecosystems can result in an infinite number of experimental combinations and conditions. By using two levels of acidification and hypoxia, this study expanded on prior investigations (Clark and Gobler, 2016) and provided two benchmark conditions to compare the diurnally cycling $\mathrm{pH}$ and $\mathrm{DO}$ to: the same mean conditions and the low, minimum condition achieved at night only. While the absolute levels of low $\mathrm{pH}$ and DO used in this study were more severe than coastal shelf ecosystems (Wootton et al., 2008; Hofmann et al., 2011; Cornwall et al., 2013) they were consistent with observations made in temperate estuaries during summer months (Ringwood and Keppler, 2002; Baumann et al., 2014).

During this study, the combined effects of hypoxia and acidification were more severe than those observed for acidification alone. For both larval clams and scallops, growth, and survival rates under diurnally-fluctuating $\mathrm{pH}$ and $\mathrm{DO}$ were significantly lower than the rates for individuals continuously exposed to the same mean $\mathrm{pH}$ and DO levels (e.g., intermediate conditions in Figures 6, 7). Instead, survival rates for both species under diurnally-fluctuating $\mathrm{pH}$ and $\mathrm{DO}$ were equal to rates experienced by individuals in the "low" treatments that were, on average, chronically exposed to $\mathrm{pH}$ levels $0.3-0.4$ units lower and DO levels more than $2 \mathrm{mg} \mathrm{L}^{-1}$ lower. This 
TABLE 6 | Mean ( \pm standard deviation) pH, dissolved oxygen (DO), $\mathrm{pCO}_{2}$, saturation states of calcite and aragonite, total dissolved inorganic carbon (TDIC), carbonate, total alkalinity (TA), salinity, and temperature for the four treatment larval Mercenaria mercenaria diurnal acidification and hypoxia experiment.

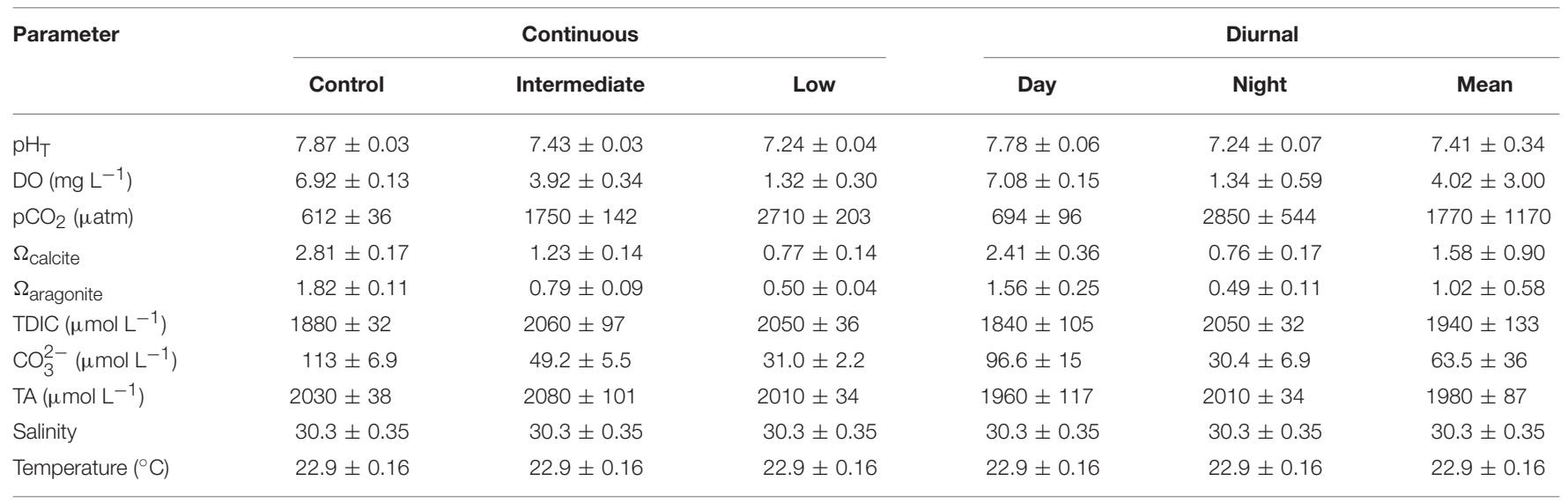

finding of diurnal fluctuations yielding more dire physiological outcomes is consistent with studies of isopods and calcifying algae exposed to diurnal acidification (Alenius and Munguia, 2012; Cornwall et al., 2013). It is also consistent with our prior study examining only one level of $\mathrm{pH}$ and $\mathrm{DO}$ during which the performance of larval bivalves experiencing diurnal acidification and/or hypoxia was generally worse than that of individuals exposed to the same mean conditions (Clark and Gobler, 2016). Here, by examining multiple levels of $\mathrm{pH}$ and DO, the quantitative extent of impairment due to diurnal changes in acidification and hypoxia was identified and affirmed that large diurnal changes in $\mathrm{pH}$ and $\mathrm{DO}$ have strong negative effects on early-life stage bivalves. While bivalves have a series of physiological adaptions to acclimate to low $\mathrm{pH}$ and low DO including acid-base regulation, anaerobic metabolism, and metabolic depression (Grieshaber et al., 1994; Guppy and Withers, 1999; Hochachka and Lutz, 2001; Wu, 2002; Michaelidis et al., 2005), it would seem these processes are ineffective against the combined level and variation of acidification and hypoxia at least for larval bivalves which may have more poorly developed physiological systems for resisting physiological stress. While it is probable that juvenile-stage bivalves with more well-developed physiological systems may be better able to adapt to diurnal changes on $\mathrm{pH}$ and $\mathrm{DO}$, this has yet to be explored.

In conclusion, the effects of diurnal acidification alone on early-life stage bivalves were consistent with the effects consistent exposure to the same mean levels of $\mathrm{pH}$, indicating the individuals could tolerate extreme acidification if normal $\mathrm{pH}$ conditions were encountered for an extended period daily. In contrast, the dual, diurnal variation in $\mathrm{pH}$ and $\mathrm{DO}$ associated with acidification and hypoxia yielded survival rates for larval bivalves that were not statistically different to individuals experiencing drastically lower levels of $\mathrm{pH}$ and DO. Given that high rates of ecosystem metabolism in eutrophic estuaries can causes $\mathrm{pH}$ and DO to undergo large diurnal changes (Ringwood and Keppler, 2002; Yates et al., 2007; Baumann et al., 2014) during the times of the year when early-life stage bivalves are present in estuaries (Kraeuter and Castagna, 2001; Shumway and Parsons, 2011), it is likely that these conditions have diminished and shaped abundances and growth rates in some bivalve populations (O'Leary et al. submitted). In the absence of nutrient abatement to lessen extremes in eutrophic-driven acidification and hypoxia (Wallace et al., 2014), it should be expected that climate change will lead to both greater extremes and lower levels of pH and DO (Rabalais et al., 2002; Miller et al., 2009; Feely et al., 2010) and thus lead to even greater losses for these populations.

\section{ETHICS STATEMENT}

All organisms used for this research were marine invertebrate bivalves and as such were not subject to Institutional Animal Care and Use Committee (IACUC; USA) oversight. However, care was taken in designing experiments to limit and reduce the number animals sacrificed during the course of research. All organisms prior to and after experimentation were adequately fed, maintained at optimal densities, and routinely cared for.

\section{AUTHOR CONTRIBUTIONS}

CG-obtained funding, designed experiments, analyzed data, and wrote manuscript. HC-designed experiments, conducted experiments, analyzed experimental results, and wrote manuscript. AG-designed experiments, analyzed experimental results, and wrote manuscript. ML-aided in conducting experiments and edited manuscript.

\section{FUNDING}

This work was supported by New York Sea Grant Award R-FBM38, the Laurie Landeau Foundation, the Simons Foundation, and the Chicago Community Trust. 


\section{REFERENCES}

Abeels, H. A., Loh, A. N., and Volety, A. K. (2012). Trophic transfer and habitat use of oyster Crassostrea virginica reefs in southwest Florida, identified by stable isotope analysis. Mar. Ecol. Prog. Ser. 462, 125-142. doi: 10.3354/meps 09824

Alenius, B., and Munguia, P. (2012). Effects of $\mathrm{pH}$ variability on the intertidal isopod, Paradella dianae. Mar. Freshw. Behav. Physiol. 45, 245-259. doi: 10.1080/10236244.2012.727235

Baumann, H., Wallace, R. B., Tagliaferri, T., and Gobler, C. J. (2014). Large natural $\mathrm{pH}, \mathrm{CO}_{2}$ and $\mathrm{O}_{2}$ fluctuations in a temperate tidal salt marsh on diel, seasonal, and interannual time scales. Estuar. Coasts 38, 220-231. doi: $10.1007 /$ s12237-014-9800-y

Caffrey, J. M. (2004). Factors controlling net ecosystem metabolism in U.S. estuaries. Estuaries 27, 90-101. doi: 10.1007/BF02803563

Cai, W.-J., Hu, X., Huang, W.-J., Murrell, M. C., Lehrter, J. C., Lohrenz, S. E., et al. (2011). Acidification of subsurface coastal waters enhanced by eutrophication. Nat. Geosci. 4, 766-770. doi: 10.1038/ngeo1297

Clark, H. R., and Gobler, C. J. (2016). Do diurnal fluctuations in $\mathrm{CO}_{2}$ and dissolved oxygen concentrations provide a refuge from hypoxia and acidification for early life stage bivalves? Mar. Ecol. Prog. Ser. 558, 1-14. doi: 10.3354/meps 11852

Coen, L. D., Brumbaugh, R. D., Bushek, D., Grizzle, R., Luckenbach, M. W., Posey, M. H., et al. (2007). Ecosystem services related to oyster restoration. Mar. Ecol. Prog. Ser. 341, 303-307. doi: 10.3354/meps341303

Cornwall, C. E., Hepburn, C. D., McGraw, C. M., Currie, K. I., Pilditch, C. A., Hunter, K. A., et al. (2013). Diurnal fluctuations in seawater $\mathrm{pH}$ influence the response of a calcifying macroalga to ocean acidification. Proc. Biol. Sci. 280:20132201. doi: 10.1098/rspb.2013.2201

Del Giorgio, P. A., and Williams, P. J. (2005). Respiration in Aquatic Ecosystems. New York, NY: Oxford University Press.

Diaz, R. J., and Rosenberg, R. (2008). Spreading dead zones and consequences for marine ecosystems. Science 321, 926-929. doi: 10.1126/science.1156401

Dickson, A. G. (1993). The measurement of sea water pH. Mar. Chem. 44, 131-142. doi: 10.1016/0304-4203(93)90198-W

Doney, S. C., Fabry, V. J., Feely, R. A., and Kleypas, J. A. (2009). Ocean acidification: the other $\mathrm{CO}_{2}$ problem. Ann. Rev. Mar. Sci. 1, 169-192. doi: 10.1146/annurev.marine.010908.163834

Doney, S. C., Ruckelshaus, M., Duffy, J. E., Barry, J. P., Chan, F., English, C. A., et al. (2012). Climate change impacts on marine ecosystems. Ann. Rev. Mar. Sci. 4, 11-37. doi: 10.1146/annurev-marine-041911-111611

Ekstrom, J. A., Suatoni, L., Cooley, S. R., Pendleton, L. H., Waldbusser, G. G., Cinner, J. E., et al. (2015). Vulnerability and adaptation of US shellfisheries to ocean acidification. Nat. Clim. Chang. 5, 207-214. doi: 10.1038/nclimate2508

Feely, R. A., Alin, S. R., Newton, J., Sabine, C. L., Warner, M., Devol, A., et al. (2010). The combined effects of ocean acidification, mixing, and respiration on $\mathrm{pH}$ and carbonate saturation in an urbanized estuary. Estuar. Coast. Shelf Sci. 88, 442-449. doi: 10.1016/j.ecss.2010.05.004

Fegley, S. R. (2001). "Demography and dynamics of hard clam populations," in Biology of the Hard Clam, eds J. N. Kraeuter and M. Castagna (Amsterdam: Elsevier Science), 383-422.

Gazeau, F., Parker, L. M., Comeau, S., Gattuso, J.-P., O’Connor, W. A., Martin, S., et al. (2013). Impacts of ocean acidification on marine shelled molluscs. Mar. Biol. 160, 2207-2245. doi: 10.1007/s00227-013-2219-3

Gobler, C. J., and Baumann, H. (2016). Hypoxia and acidification in ocean ecosystems: coupled dynamics and effects on marine life. Biol. Lett. 12:20150976. doi: 10.1098/rsbl.2015.0976

Gobler, C. J., DePasquale, E. L., Griffith, A. W., and Baumann, H. (2014). Hypoxia and acidification have additive and synergistic negative effects on the growth, survival, and metamorphosis of early life stage bivalves. PLoS ONE 9:e83648. doi: 10.1371/journal.pone.0083648

Gobler, C. J., and Talmage, S. C. (2013). Short- and long-term consequences of larval stage exposure to constantly and ephemerally elevated carbon dioxide for marine bivalve populations. Biogeosciences 10, 2241-2253. doi: 10.5194/bg-10-2241-2013

Green, M. A., and Aller, R. C. (1998). Seasonal patterns of carbonate diagenesis in nearshore terrigenous muds: relation to spring phytoplankton bloom and temperature. J. Mar. Res. 56, 1097-1123. doi: 10.1357/002224098765 173473
Green, M. A., Waldbusser, G. G., Reilly, S. L., Emerson, K., and O’Donnell, S. (2009). Death by dissolution: sediment saturation state as a mortality factor for juvenile bivalves. Limnol. Oceanogr. 54, 1037-1047. doi: 10.4319/lo.2009.54.4.1037

Grieshaber, M. K., Hardewig, I., Kreutzer, U., and Pörtner, H. O. (1994). Physiological and metabolic responses to hypoxia in invertebrates. Rev. Physiol. Biochem. Pharmacol. 125, 43-147. doi: 10.1007/bfb0030909

Guppy, M., and Withers, P. (1999). Metabolic depression in animals: physiological perspectives and biochemical generalizations. Biol. Rev. Camb. Philos. Soc. 74, 1-40. doi: $10.1017 /$ S0006323198005258

Helm, M. M., Bourne, N., and Lovatelli, A. (2004). Hatchery Culture of Bivalves: A Practical Manual. Rome: Food and Agriculture Organization of the United Nations.

Hochachka, P. W., and Lutz, P. L. (2001). Mechanism, origin, and evolution of anoxia tolerance in animals. Comp. Biochem. Physiol. B Biochem. Mol. Biol. 130, 435-459. doi: 10.1016/S1096-4959(01)00408-0

Hofmann, G. E., Smith, J. E., Johnson, K. S., Send, U., Levin, L. A., Micheli, F., et al. (2011). High-frequency dynamics of ocean $\mathrm{pH}$ : a multi-ecosystem comparison. PLoS ONE 6:e28983. doi: 10.1371/journal.pone.0028983

Keppel, A. G., Breitburg, D. L., and Burrell, R. B. (2016). Effects of co-varying dielcycling hypoxia and $\mathrm{pH}$ on growth in the Juvenile Eastern Oyster, Crassostrea virginica. PLoS ONE 11:e0161088. doi: 10.1371/journal.pone.0161088

Kim, T. W., Barry, J. P., and Micheli, F. (2013). The effects of intermittent exposure to low-pH and low-oxygen conditions on survival and growth of juvenile red abalone. Biogeosciences 10, 7255-7262. doi: 10.5194/bg-10-7255-2013

Kraeuter, J. N., and Castagna, M. (2001). Biology of the Hard Clam. Amsterdam: Elsevier.

Kraeuter, J. N., Castagna, M., and van Dessel, R. (1981). Egg size and larval survival of Mercenaria mercenaria (L.) and Argopecten irradians (Lamarck). J. Exp. Mar. Biol. Ecol. 56, 3-8. doi: 10.1016/0022-0981(81)90003-4

Kroeker, K. J., Kordas, R. L., Crim, R., Hendriks, I. E., Ramajo, L., Singh, G. S., et al. (2013). Impacts of ocean acidification on marine organisms: quantifying sensitivities and interaction with warming. Glob. Chang. Biol. 19, 1884-1896. doi: $10.1111 / \mathrm{gcb} .12179$

Melzner, F., Thomsen, J., Koeve, W., Oschlies, A., Gutowska, M. A., Bange, H. W., et al. (2012). Future ocean acidification will be amplified by hypoxia in coastal habitats. Mar. Biol. 160, 1875-1888. doi: 10.1007/s00227-012-1954-1

Meyer, D. L., Townsend, E. C., and Thayer, G. W. (1997). Stabilization and erosion control value of oyster cultch for intertidal marsh. Restor. Ecol. 5, 93-99. doi: 10.1046/j.1526-100X.1997.09710.x

Michaelidis, B., Ouzounis, C., Paleras, A., and Pörtner, H. O. (2005). Effects of long-term moderate hypercapnia on acid-base balance and growth rate in marine mussels Mytilus galloprovincialis. Mar. Ecol. Prog. Ser. 293, 109-118. doi: 10.3354/meps293109

Miller, A. W., Reynolds, A. C., Sobrino, C., and Riedel, G. F. (2009). Shellfish face uncertain future in high $\mathrm{CO}_{2}$ world: influence of acidification on oyster larvae calcification and growth in estuaries. PLOS ONE 4:e5661. doi: 10.1371/journal.pone.0005661

Millero, F. J., Graham, T. B., Huang, F., Bustos-Serrano, H., and Pierrot, D. (2006). Dissociation constants of carbonic acid in seawater as a function of salinity and temperature. Mar. Chem. 100, 80-94. doi: 10.1016/j.marchem.2005.12.001

Officer, C. B., Smayda, T. J., and Mann, R. (1982). Benthic filter feeding - a natural eutrophication control. Mar. Ecol. Prog. Ser. 9, 203-210. doi: 10.3354/meps009203

Paulmier, A., Ruiz-Pino, D., and Garçon, V. (2011). $\mathrm{CO}_{2}$ maximum in the oxygen minimum zone (OMZ). Biogeosciences 8, 239-252. doi: 10.5194/bg-8-239-2011

Pörtner, H. (2008). Ecosystem effects of ocean acidification in times of ocean warming: a physiologist's view. Mar. Ecol. Prog. Ser. 373, 203-217. doi: $10.3354 /$ meps 07768

Pörtner, H. O., Langenbuch, M., and Reipschlager, A. (2004). Biological impact of elevated ocean $\mathrm{CO}_{2}$ concentrations: lessons from animal physiology and earth history. J. Oceanogr. 60, 705-718. doi: 10.1007/s10872-004-5763-0

Rabalais, N. N., Turner, R. E., and Wiseman, W. J. (2002). Gulf of Mexico Hypoxia, A.K.A. "The Dead Zone". Annu. Rev. Ecol. Syst. 33, 235-263. doi: 10.1146/annurev.ecolsys.33.010802.150513

Ringwood, A. H., and Keppler, C. J. (2002). Water quality variation and clam growth: is $\mathrm{pH}$ really a non-issue in estuaries? Estuaries 25, 901-907. doi: 10.1007/BF02691338 
Shumway, S. E., Davis, C., Downey, R., Karney, R., Kraeuter, J., Parsons, J., et al. (2003). Shellfish aquaculture-in praise of sustainable economies and environments. World Aquac. 34, 8-10.

Shumway, S. E., and Parsons, G. J. (2011). Scallops: Biology, Ecology and Aquaculture. Amsterdam: Elsevier.

Sokolova, I. M. (2013). Energy-limited tolerance to stress as a conceptual framework to integrate the effects of multiple stressors. Integr. Comp. Biol. 53, 597-608. doi: 10.1093/icb/ict028

Steckbauer, A., Ramajo, L., Hendriks, I. E., Fernandez, M., Lagos, N. A., Prado, L., et al. (2015). Synergistic effects of hypoxia and increasing $\mathrm{CO}_{2}$ on benthic invertebrates of the central Chilean coast. Front. Mar. Sci. 2:49. doi: 10.3389/fmars.2015.00049

Talmage, S. C., and Gobler, C. J. (2009). The effects of elevated carbon dioxide concentrations on the metamorphosis, size, and survival of larval hard clams (Mercenaria mercenaria), bay scallops (Argopecten irradians), and Eastern oysters (Crassostrea virginica). Limnol. Oceanogr. 54, 2072-2080. doi: 10.4319/lo.2009.54.6.2072

Talmage, S. C., and Gobler, C. J. (2010). Effects of past, present, and future ocean carbon dioxide concentrations on the growth and survival of larval shellfish. Proc. Natl. Acad. Sci. U.S.A. 107, 17246-17251. doi: 10.1073/pnas.0913804107

Talmage, S. C., and Gobler, C. J. (2011). Effects of elevated temperature and carbon dioxide on the growth and survival of larvae and juveniles of three species of northwest Atlantic bivalves. PLoS ONE 6:e26941. doi: 10.1371/journal.pone.0026941

Tettelbach, S. T., Peterson, B. J., Carroll, J. M., Furman, B. T., Hughes, S. W. T., Havelin, J., et al. (2015). Aspiring to an altered stable state: rebuilding of bay scallop populations and fisheries following intensive restoration. Mar. Ecol. Prog. Ser. 529, 121-136. doi: 10.3354/meps11263

Tolley, S. G., and Volety, A. K. (2005). The role of oysters in habitat use of oyster reefs by resident fishes and decapod crustaceans. J. Shellfish Res. 24, 1007-1012. doi: 10.2983/0730-8000(2005)24[1007:TROOIH]2.0.CO;2

Vance, R. R. (1973). On reproductive strategies in marine benthic invertebrates. Am. Nat. 107, 339-352. doi: 10.1086/282838

Waldbusser, G. G., Brunner, E. L., Haley, B. A., Hales, B., Langdon, C. J., and Prahl, F. G. (2013). A developmental and energetic basis linking larval oyster shell formation to acidification sensitivity. Geophys. Res. Lett. 40, 2171-2176. doi: 10.1002/grl.50449
Waldbusser, G. G., Hales, B., Langdon, C. J., Haley, B. A., Schrader, P., Brunner, E. L., et al. (2014). Saturation-state sensitivity of marine bivalve larvae to ocean acidification. Nat. Clim. Chang. 5, 273-280. doi: 10.1038/nclimate 2479

Waldbusser, G. G., Hales, B., Langdon, C. J., Haley, B. A., Schrader, P., Brunner, E. L., et al. (2015). Ocean acidification has multiple modes of action on bivalve larvae. PLOS ONE 10:e0128376. doi: 10.1371/journal.pone.01 28376

Wall, C. C., Peterson, B. J., and Gobler, C. J. (2008). Facilitation of seagrass Zostere marina productivity by suspension-feeding bivalves. Mar. Ecol. Prog. Ser. 357, 165-174. doi: 10.3354/meps07289

Wallace, R. B., Baumann, H., Grear, J. S., Aller, R. C., and Gobler, C. J. (2014) Coastal ocean acidification: the other eutrophication problem. Estuar. Coast. Shelf Sci. 148, 1-13. doi: 10.1016/j.ecss.2014.05.027

Widdicombe, S., and Spicer, J. I. (2008). Predicting the impact of ocean acidification on benthic biodiversity: what can animal physiology tell us? J. Exp. Mar. Biol. Ecol. 366, 187-197. doi: 10.1016/j.jembe.2008.07.024

Wootton, J. T., Pfister, C. A., and Forester, J. D. (2008). Dynamic patterns and ecological impacts of declining ocean $\mathrm{pH}$ in a high-resolution multi-year dataset. Proc. Natl. Acad. Sci. U.S.A. 105, 18848-18853. doi: $10.1073 /$ pnas.0810079105

Wu, R. S. (2002). Hypoxia: from molecular responses to ecosystem responses. Mar. Pollut. Bull. 45, 35-45. doi: 10.1016/S0025-326X(02)00061-9

Yates, K. K., Dufore, C., Smiley, N., Jackson, C., and Halley, R. B. (2007). Diurnal variation of oxygen and carbonate system parameters in Tampa Bay and Florida Bay. Mar. Chem. 104, 110-124. doi: 10.1016/j.marchem.2006.12.008

Conflict of Interest Statement: The authors declare that the research was conducted in the absence of any commercial or financial relationships that could be construed as a potential conflict of interest.

Copyright (c) 2017 Gobler, Clark, Griffith and Lusty. This is an open-access article distributed under the terms of the Creative Commons Attribution License (CC BY). The use, distribution or reproduction in other forums is permitted, provided the original author(s) or licensor are credited and that the original publication in this journal is cited, in accordance with accepted academic practice. No use, distribution or reproduction is permitted which does not comply with these terms. 